\title{
A Study of Current Status of Drinking Water in Pokhara Metropolitan City of Nepal
}

\author{
Ishwar Prasad $^{1}$ and Rajendra P. Adhikari ${ }^{2}$ \\ ${ }^{1}$ Ph.D. Scholar, Singhania University, Rajasthan, India (Email: pdishwar@ gmail.com) \\ ${ }^{2}$ Professor of Construction Management and Chair of Advanced Research \& Training Institute (ARTIst), \\ Nepal (Email: Adhikari_rajendra@outlook.com)
}

\begin{abstract}
Management of drinking water has been a global issue and has emerged as big challenge in cities especially for developing countries. Nepal is one of the least developed countries and all cities of the country is facing this challenge along with its capital city Kathmandu. Nepal has started implementing federal system with creation of seven provinces and 753 local governments. This study analyzes the current status of demand and supply of drinking water in Pokhara Metropolitan City, the second largest city of Nepal in terms of population and largest city in terms of area and forecasts the demand and supply of drinking water in the year 2021 and 2031 in the city. Relevant formula has been used to forecast the demand and supply and published data were used for discussion and analysis. This study will help the concerned authority in forming its water related policy and will be beneficial for other growing cities as reference. This study revealed that water demand will reach $65 \mathrm{ml} / \mathrm{d}$ in 2021 and $108 \mathrm{ml} / \mathrm{d}$ in 2031. So, in the existing condition, the gap between demand and supply will continue in future also.
\end{abstract}

Keywords: Demand, Drinking water, Quality, Quantity, Supply, Water.

\section{Introduction}

The newly promulgated constitution of Nepal (Enforced from 20 September 2015) provides access to clean drinking water and sanitation (Sub-Section 35(4)). Additionally, the United Nations Sustainable Development Goals (SDGs) aimed to end poverty, protect the planet, and ensure prosperity for all, and scheduled to achieve over the next decade. Among 17 SDGs, SDG 6 targets for universal and equitable access to safe and affordable drinking water and adequate sanitation facilities for all people by the year 2030 and Nepal has already expressed its commitment to meet the SDG 6 (The Rising Nepal, March 22, 2019).

Pokhara is the second largest city of the country in terms of population with population of 414,141 (Ministry of Population and Environment, 2017). Like most of the cities of the developing countries, it is also facing challenge of managing drinking water and to cater the demand of urbanization in the context of recently created capital city of the Gandaki province. It is proven fact that if people do not have access to safe drinking water and sanitation, there will be higher risk in their health condition. Diarrheal infection alone is responsible for 0.5 million deaths of under 5 children a year worldwide (WHO, 2017).

In the above mentioned context, this paper analyzes the status of drinking water in Pokhara Metropolitan City and forecasts the demand and supply status in 2021 and 2031 so that the 
forecast helps the concerned authority to plan for sustainable and safe drinking water to its people.

\section{Objectives}

The main objectives of the study are:

(i) to identify the status of drinking water in Pokhara Metropolitan City (PMC), and

(ii) to predict future demand and supply of drinking water in PMC in the year 2021 and 2031.

\section{Methodology}

This paper is based on secondary data relevant to drinking water and Pokhara. For population forecast, Geometrical Increase Method has been used. This method is based on the assumption that the percentage increase in population from decade to decade remains constant. Therefore, the average value of the percentage increase is calculated, and the future populations are calculated at this rate. For a young city which at present is expanding at faster rate, this method may give very high results, and is useful for old developed cities. The step involved in this method is as follows (Garg, 1990).First calculate rate of growth (r) per decade, i.e. $r_{1}, r_{2} \ldots \ldots$

- Calculate Geometric Mean $r_{g}=\left(\mathbf{r}_{1} \times \mathbf{r}_{2}\right)^{1 / n}$

- Assume that the future growth follows the geometric mean

If the population is $\mathrm{P}$ and average percentage growth is $r_{g}$ then population at the end of $n$ decades will be

$\mathrm{P}_{\mathrm{n}}=\mathrm{P}_{\mathrm{o}}\left(1+\mathrm{r}_{\mathrm{g}} / 100\right)^{\mathrm{n}}$

Where, $\mathrm{P}_{\mathrm{n}}=$ Probable population after interval of $\mathrm{n}$ decades.

$\mathrm{P}_{\mathrm{O}=}$ Population of the last decade.

$\mathbf{n}=$ number of decade considered.

Analyzing the data received from the above, demand and supply status of drinking water for PMC is projected and relevant recommendations were made.

\section{Brief history of drinking water in Pokhara}

Piped water supply system in Pokhara was started in 1920 A.D. from hillside spring of Baldhara. The system was institutionalized after commissioning of Bhote Khola Scheme in 1965. Water Supply and Sewerage Board (WSSB) ${ }^{3}$ was formed from Pani Adda or Pani Goswara ${ }^{4}$ which was in operation to provide safe water and adequate sanitation facilities to the urban people. After establishment of the WSSB, systematic planning and selection of new project was started from 1975 in Pokhara. In 1978, Kalimundha Scheme was completed with 500 cum capacity reservoir tank at Amalabishauni which has $250 \mathrm{~mm}$ dia. D.I. pipe whose length is $7 \mathrm{~km}$. However, it was not sufficient water supply in the distribution system. The scenic beauty of Pokhara attracts a large number of tourists and it started to grow as a political, economic, cultural, industrial and major tourist center of the country.

\footnotetext{
${ }^{3}$ Water Supply and Sewerage Board (WSSB) was established on July 1973 and was in operation up to July 1985under the Development Board Act, 1957 and became Water Supply and Sewerage Corporation (WSSC) from July 1985 to February 1990 under the Corporation Act, 1965. Later it became Nepal Water Supply Corporation (NWSC) from February 1990 to date under Nepal Water Supply Corporation Act, 1990.

${ }^{4}$ Pani Adda or Pani Goswara was in operation from May 1973 to July 1973.
} 
The population of Pokhara in 1981 was 46,642 with a growth rate of $8.51 \%$ for the period 1971 - 1981. To mitigate the problem of water scarcity, WSSC proposed Mardi Scheme as a durable and sufficient source of drinking water for then Pokhara Sub Metropolitan City. Now it has become Pokhara Metropolitan City. In 1987, a trunk main of D.I. $400 \mathrm{~mm}$ dia. pipe up to Amalabisauni reservoir was completed, which added 16 million liters per day of water to Pokhara. Before $25^{\text {th }}$ August 2011, water demand was $28.78 \mathrm{ml} / \mathrm{d}$ and supply was only 22.35 $\mathrm{ml} / \mathrm{d}$ (NWSC, 2012). The demand for tap water was very high so NWSC has not been able to fulfill the drinking water demand of the people until now. So, NWSC had decided to launch a project named "Pokhara Water Supply Improvement Scheme" on $3^{\text {rd }}$ June, 2009 to meet water demands of the city. Total cost of the project was NPR 130.5 million among which D.I. Pipes and fittings costing NPR 80.5 million was received from Japan International Cooperation Agency (JICA) and remaining cost was governed by Government of Nepal (GoN).This project added $25 \mathrm{ml} / \mathrm{d}$ water in the system.

Additionally this project constructed parallel line of $500 \mathrm{~mm}$ dia. D.I. pipe from the existing Mardi intake to the Bindhyabasini reservoir site, where new additional three reservoirs of capacity 500 cum each was constructed along with:

(i) Laying and joining of $500 \mathrm{~mm}$ dia. Tyton Joint D.I. Pipeline from Mardi River Intake to Bindhyabashni Reservoir (including Fabrication and Installation of M.S. Truss Bridge 16 $\mathrm{m}$ and $25 \mathrm{~m}$ span) in Pokhara.

(ii) 500 mmdia. D.I. Pipe, 11 K.M. Pipeline from Mardi Intake to Bindhyabasini Reservoir produces $25 \mathrm{ml} / \mathrm{d}$ water in the system. So, total production of water is $48.75 \mathrm{ml} / \mathrm{d}$ and after leakage deduction it is only $39 \mathrm{ml} / \mathrm{d}$.

From the above projects and effort, significant quantity of drinking water was added but still the demand remains higher than the supply. More quantity of water is generated and added but the quality is not satisfactory. The distribution network is very old (1920-1978)and it is under size (maximum size is $250 \mathrm{~mm}$ dia.). Realizing these problems, the Government of Japan provided grant support for improvement of water supply services of Pokhara city and on February 15, 2017, Nepal Government and JICA signed for a grant amounting NRs. 4.8 billion (NWSC, 2017). The project is scheduled to complete in December 2022 (JICA, 2019). The major components of this project are as follows: -

(a) Water Treatment Plant:

Grit Chamber- 4 unit (capacity 42 MLD) ---Near Mardi River Intake

Sedimentation Tank - 4 unit (capacity 42 MLD) ---Near Mardi River Intake

Slow Sand Filter- 6 unit (capacity 41 MLD) ---Puranchaur

Clear water reservoir- $2 \times 930$ cubic meter ---Puranchaur

Chlorination plant

---Puranchaur

(b) Service Reservoirs and pipeline works:

Prashyang (Ward No 5) -----2 million liters capacity

Phulbari(Ward No 11) -----2 million liters capacity

Kolpatan(Ward No 15) -----2 million liters capacity (Overhead)

Pipeline work

-----about $113 \mathrm{~km}$ (transmission, distribution main \& sub-mains) 


\section{Analysis and Findings:}

\section{Water demand and supply}

From the very beginning the demand of water was recorded as more than the supply. In 1971 demand was $8 \mathrm{ml} / \mathrm{d}$ and the average water production was $5 \mathrm{ml} / \mathrm{d}$. The gap was becoming wider and in 2011 the demand was $42 \mathrm{ml} / \mathrm{d}$ whereas average production was only $22.9 \mathrm{ml} / \mathrm{d}(54.5 \%$ of the demand). The demand and supply of drinking water in 2011 was shown in table 1.

Table 1: Water Demand and Supply

\begin{tabular}{|c|c|c|c|c|c|}
\hline S.N. & $\begin{array}{c}\text { Year } \\
\text { (A.D.) }\end{array}$ & $\begin{array}{c}\text { Wet Season Supply } \\
\text { Per day (ml/d) }\end{array}$ & $\begin{array}{c}\text { Dry Season Supply } \\
\text { Per day }(\mathrm{ml} / \mathrm{d})\end{array}$ & $\begin{array}{c}\text { Average Water } \\
\text { Production After } \\
\text { Leakage }(\mathrm{ml} / \mathrm{d})\end{array}$ & $\begin{array}{c}\text { Water Demand in } \\
(\mathrm{ml} / \mathrm{d})\end{array}$ \\
\hline 1. & 1971 & 6.5 & 3.4 & 5 & 8 \\
\hline 2. & 1981 & 13.5 & 9.5 & 12 & 15 \\
\hline 3. & 1991 & 22.73 & 19.4 & 21.07 & 25 \\
\hline 4. & 2001 & 22.73 & 19.4 & 21.07 & 32.9 \\
\hline 5. & 2011 & 24.50 & 21.30 & 22.9 & 42 \\
\hline
\end{tabular}

(Source: NWSC, 2011)

As shown in table 2, population of Pokhara city is considerably increasing. Urban population in the year 1971 was only 20,611 , which was 258,705 in the year 2011 . This shows there was drastic change in the population over the years.

Table 2: Population \& its Growth (1952 -2011)

\begin{tabular}{|c|c|c|}
\hline \multirow{2}{*}{ Years } & \multicolumn{2}{|c|}{ Pokhara Metropolitan City } \\
\cline { 2 - 3 } & Population & Growth rate (\%) \\
\hline $1952 / 54$ & 3,755 & - \\
\hline 1961 & 5,413 & 5.36 \\
\hline 1971 & 20,611 & 14.30 \\
\hline 1981 & 46,642 & 8.51 \\
\hline 1991 & 95,286 & 7.41 \\
\hline 2001 & 156,312 & 5.6 \\
\hline 2011 & 258,705 & 4 \\
\hline
\end{tabular}

$(C B S, 2011)$

In 2019, Pokhara branch office of NWSC has started to produce drinking water about $39 \mathrm{ml} / \mathrm{d}$ by using surface as well as deep tube well. The capacity of the surface and ground water sources are shown in table 3.

Table 3: Existing Surface and Ground Water Production

\begin{tabular}{|c|c|c|c|c|c|}
\hline \multirow{2}{*}{ S.N. } & \multirow{2}{*}{ Name of Intakes } & \multirow{2}{*}{$\begin{array}{c}\text { Year of } \\
\text { Construction } \\
\text { (In A.D.) }\end{array}$} & \multirow{2}{*}{$\begin{array}{c}\text { Design } \\
\text { Yield } \\
\text { (in ml/d) }\end{array}$} & \multicolumn{2}{|c|}{ Present Yield (ml/d) } \\
\hline & & & & Wet Season & $\begin{array}{c}\text { Dry } \\
\text { Season }\end{array}$ \\
\hline A. & Surface Water Source & & & & \\
\hline 1. & Baldhara & 1920 & 0.5 & 0.5 & 0.4 \\
\hline 2. & Bhote Khola & 1965 & 5 & 3.0 & 1.0 \\
\hline 3. & Kali Khola & 1978 & 8 & 3.0 & 2.0 \\
\hline
\end{tabular}




\begin{tabular}{|c|l|c|c|c|c|}
\hline 4. & Mardi Khola $(400 \mathrm{~mm})$ & 1987 & 16 & 16 & 16 \\
\hline 5. & Mardi Khola $(500 \mathrm{~mm})$ & 2011 & 25 & 25 & 25 \\
\hline B. & Ground Water Sources & & & & \\
\hline 1. & Shri Krishna Chowk & 2004 & 0.6 & 0.50 & 0.5 \\
\hline 2. & Pardi Guest House & 2004 & 0.5 & 0.40 & 0.4 \\
\hline 3. & Phulbari & 2007 & 0.6 & 0.50 & 0.5 \\
\hline 4. & Ambarsigh & 2008 & 0.5 & 0.40 & 0.4 \\
\hline 5. & Himali Tole & 1.2 & 1.0 & 1.0 \\
\hline 6. & Chauthe Belchauthari & 2016 & 1.2 & 1.0 & 1.0 \\
\hline \multicolumn{2}{|c|}{ Total Production Capacity } & & 51.3 & 48.2 \\
\hline \multicolumn{2}{|c|}{ Aater Production After Leakages } & & 40.2 & 37.8 \\
\hline \multicolumn{2}{|c|}{} & & & 39 \\
\hline
\end{tabular}

(NWSC, 2019)

From the above discussion, it is seen that the demand of water in 2011 was $42 \mathrm{ml} / \mathrm{d}$ whereas supply was only $22.9 \mathrm{ml} / \mathrm{d}$ i.e. only $55 \%$ of the total demand. As we can see in the above Table 3 , the average water production is only $39 \mathrm{ml} / \mathrm{d}$ in the year 2019 so there is still gap between demand and supply of drinking water.

\section{Forecasting population and water demand}

Generally, population in the city goes on increasing. Population increases by birth, decreases by death, increases or decreases by migration, and increases by annexation. These all four factors affect the change in population (Rangwala et al., 1990). The future population in the town mostly depends on trade expansion, development of industries, employment opportunity etc. In the case of Pokhara, there is higher rate of population increase mostly by migration. The population growth rate of Pokhara Metropolitan City during the year $1952-2011$ is shown in Table 2. For population projection, geometric mean of growth rate has been taken for last two decades. The percentage increase in population from decade to decade is worked out as follows:

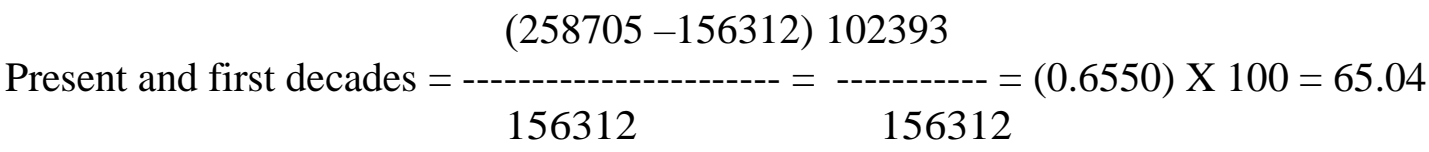

$$
\begin{aligned}
& (156312-95286) \quad 61026 \\
& \text { First and second decades }=\text {----------------- = -------- }=(0.6404) \text { X } 100=64.05 \\
& \text { Therefore, Geometric Mean }\left(\mathrm{r}_{\mathrm{g}}\right) \quad=\left(\mathrm{r}_{1} \times \mathrm{r}_{2}\right)^{1 / \mathrm{n}} \\
& =(65.04 \times 64.05)^{1 / 2} \\
& =(4165.81)^{0.5} \\
& =64.54
\end{aligned}
$$

Water demand in the year 2021 A.D.

Population of this city in $2011\left(\mathrm{P}_{\mathrm{o}}\right)$

Geometric Growth Rate $\left(r_{\mathrm{g}}\right)$

Water consumption per capita per day

Now, we have to forecast Population after 10 years (i.e. in the year 2021) 
As We Know, Population Projection $\left(P_{n}\right)=P_{o}\left(1+r_{g} / 100\right)^{n}$

Where:

$$
P_{n}=P_{o}\left(1+r_{g} / 100\right)^{n}
$$

$$
\begin{array}{lll}
\mathrm{P}_{\mathrm{n}} & = & \text { Population after } \mathrm{n} \text { decades. } \\
\mathrm{P}_{\mathrm{O}} & = & \text { Population at start in the year } 2011 . \\
\mathrm{r}_{\mathrm{g}} & = & \text { Geometric growth rate } \\
\mathrm{n} & = & \text { Number of decades }
\end{array}
$$

Therefore,

$$
\begin{aligned}
\mathrm{P}_{2021} & =258705(1+64.54 / 100)^{1} \\
& =\quad 425,673 \mathrm{Nos}
\end{aligned}
$$

$\begin{array}{ll}\text { Water Demand After ten years of this city } & =425,673 \times 125 \\ & =53,209,125 \text { litters. } \\ \text { Water Demand for Industries about } 8 \% & =4,256,730 \text { litters. } \\ \text { Leakage and Wastages about } 15 \% & =7,981,369 \text { litters. } \\ & ------------ \\ \text { Total Water Demand } & =65,447,224 \text { litters. } \\ \text { Say } & =65 \mathrm{ml} / \mathrm{d} .\end{array}$

The water demand of this city is estimated to be $65 \mathrm{ml} / \mathrm{d}$ in 2021 A.D.

\section{Water demand in the year 2031 A.D.}

$$
\begin{aligned}
\mathrm{P}_{2031}=\quad & 258705(1+64.54 / 100)^{2} \\
& =\quad 700,403.00 \text { Nos. }
\end{aligned}
$$

$$
\begin{aligned}
\text { Water Demand After twenty years of this city } & =700,403 \text { X } 125 \\
& =87,550,375 \text { litters. } \\
\text { Water Demand for Industries about } 8 \% & =7,004,030 \text { litters. } \\
\text { Leakage and Wastages about } 15 \% & =13,132,556 \text { litters. } \\
& ---------- \\
\text { Total Water Demand } & =107,686,961 \text { litters. } \\
\text { Say } & =108 \mathrm{ml} / \mathrm{d} .
\end{aligned}
$$

The water demand of this city is estimated to be $108 \mathrm{ml} / \mathrm{d}$ in the year 2031 A.D. Water demand for different decades from 1971 to 2031 is shown in figure 1. As shown in the graph, demand of water in 1971 was $8 \mathrm{ml} / \mathrm{d}$ while in 2031 is $108 \mathrm{ml} / \mathrm{d}$. Similarly, the production of water after leakage in 1971 is only $5 \mathrm{ml} / \mathrm{d}$ while in the decade 2031 is $39 \mathrm{ml} / \mathrm{d}$. This indicates a large gap in demand and supply of water in future. 
Figure 1: Water Demand \& Supply

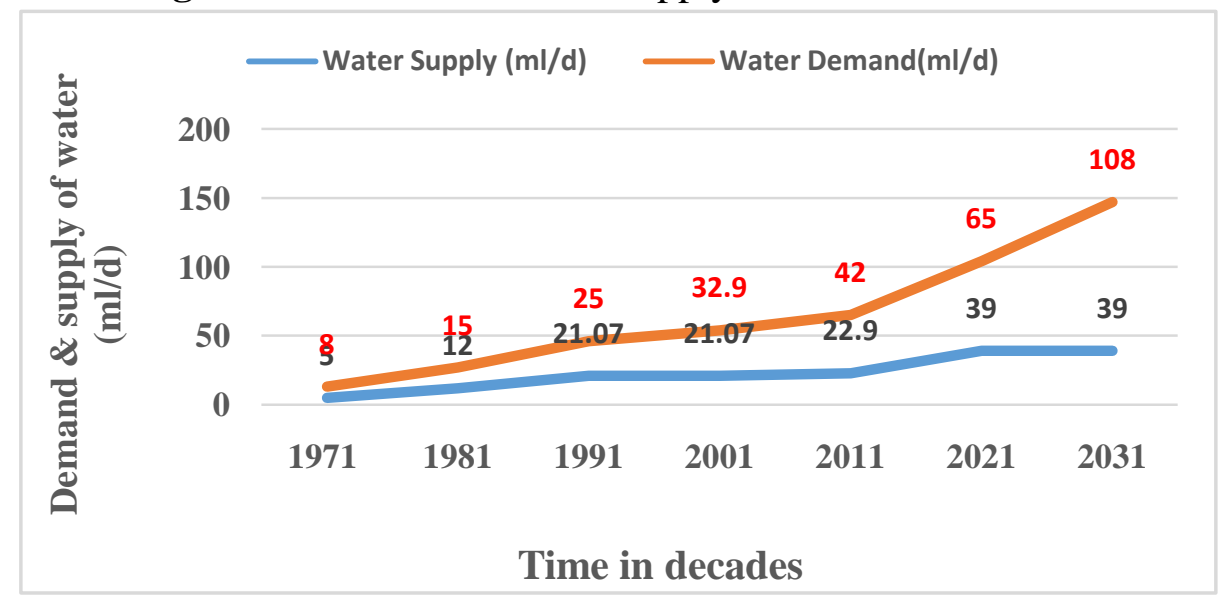

(Source: Data based on Table 1, Table 3 and above calculation)

\section{Temperature and precipitation}

Drinking water in Pokhara Metropolitan city (PMC) is managed by Nepal Water Supply Corporation (NWSC) and is supplying through surface sources as well as ground sources. There are four water sources in Pokhara of which three are surface water sources - Bhote Khola, Kali Khola, and Mardi Khola and others are ground water sources. The major source of water supply among these rivers is Mardi River which covers $84 \%$ of total water supply in Pokhara city (Refer Table 3). Mardi River discharge trends show that the discharge is gradually decreasing in the last 30 years. The data shows that annual discharge of the river was $11.74 \mathrm{~m}^{3} / \mathrm{sec}$ in 1985 , was 18.26 $\mathrm{m}^{3} / \mathrm{sec}$ in $1995,6.78 \mathrm{~m}^{3} / \mathrm{sec}$ in 2005 and $11.05 \mathrm{~m}^{3} / \mathrm{sec}$ in 2015 . It is shown in figure 2.

Figure 2: Annual Discharge of Mardi River $\left(\mathrm{m}^{3} / \mathrm{sec}\right)$

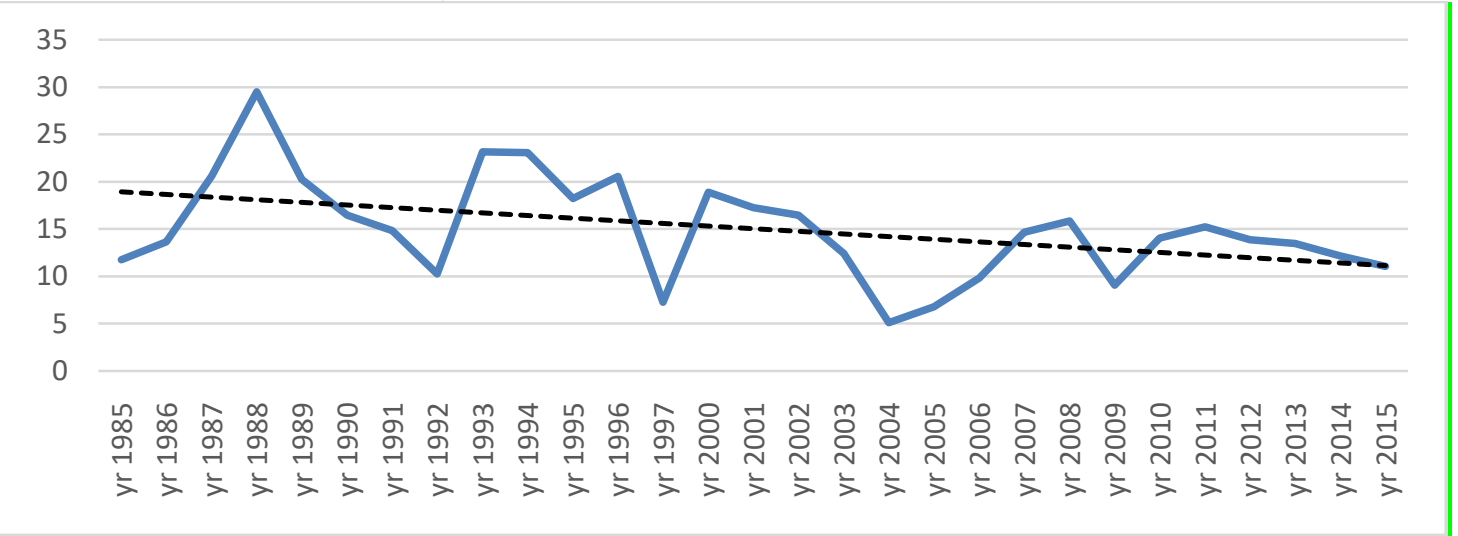

(Source: Department of Hydrology and Meteorology, 2019)

It is also to be noted here that temperature and precipitation trends in Pokhara show that average temperature is increasing at the same time average precipitation is decreasing. Additionally, discharge of major water sources such as Mardi River is also decreasing. This indicates that water availability will gradually decrease in coming years. The trends are shown in figure $3 \& 4$. 
Figure 3: Precipitation trends in Pokhara

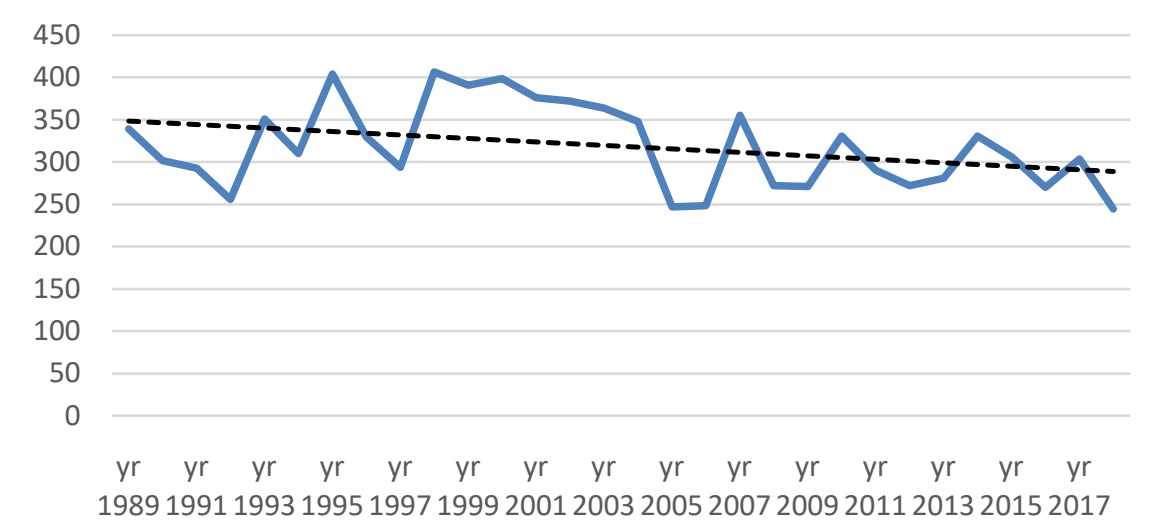

(Source: Department of Hydrology and Meteorology, 2019)

Figure 4: Temperature trends in Pokhara

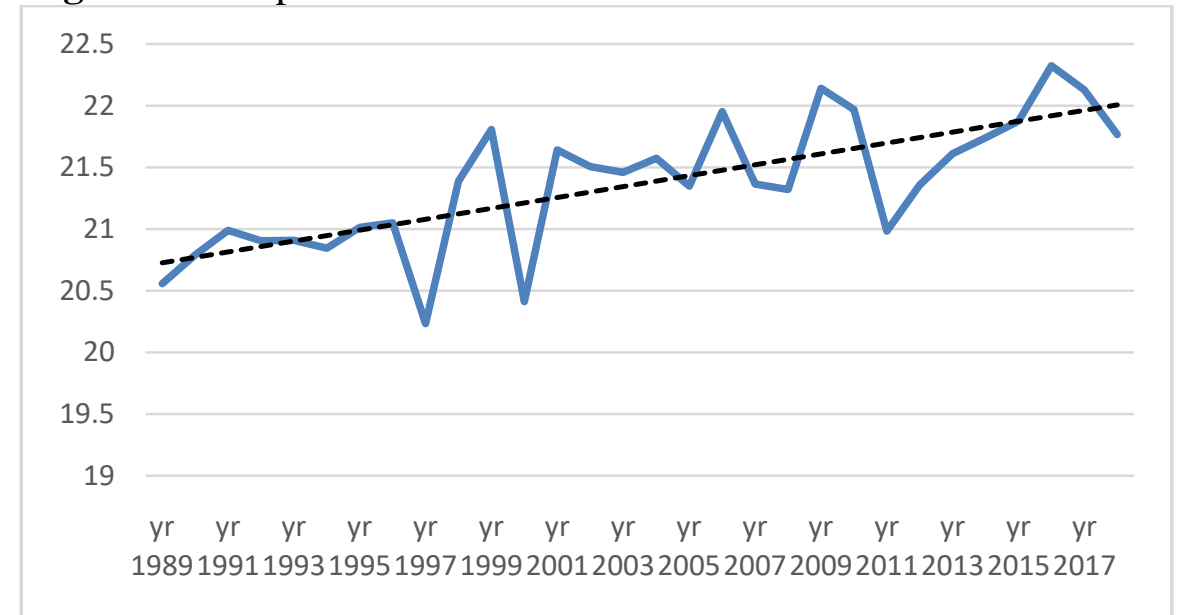

(Source: Department of Hydrology and Meteorology, 2019)

\section{Conclusion:}

Nepal Water Supply Corporation Pokhara Office is responsible for management of drinking water supply of Pokhara Metropolitan City. The system currently receives water from different surface sources as well as ground water sources. Water demand is becoming much higher than the supply. Hence, concerned organization, local government and the concerned stakeholders have to start planning to address not only to address the present shortage of drinking water but to address the future water demand also. Controlling leakage is one approach to increase supply. Besides these, conservation of water sources, collection and use of rain water and recycling and reusing of water need to promote and bring into practice. Similarly, for sustainable use of water, responsible governments - federal, provincial and local need to have clear policy and effective monitoring and implementation of the policy. 


\section{References}

CBS (2011). National Population and Housing Census (2011).National Report, volume 01. Government of Nepal. National Planning Commission Secretariat. Central Bureau of Statistics.

Garg, S. K. (1990). Water Supply Engineering(sixth and enlarged edition), p. 30 \& 32. 2-B, Nath Maket, Nai Sarak, Delhi-110006: Khana Publishers.

JICA (2019). Foundation Stone Laying Ceremony of Pokhara Water Supply Improvement Project. Retrieved on 17 July, 2019 from:https://www.jica.go.jp/nepal/english/office/topics/press190611.html

Ministry of Population and Environment (MoPE) (2017), National Population Report 2017, Ministry of Population and Environment, Government of Nepal, Kathmandu, p. 77

NWSC, (2011). Management Information Report, Nepal Water Supply Corporation. Pokhara, Nepal.

NWSC, (2012). Management Information Report, Nepal Water Supply Corporation. Pokhara, Nepal.

NWSC, (2017). 28 ${ }^{\text {th }}$ anniversary annual report (February, 26 $6^{\text {th }}$ 2017). Nepal Water Supply Corporation. Kathmandu, Nepal.

NWSC, (2019). Management Information Report, Nepal Water Supply Corporation. Kathmandu, Nepal.

Rangwala, S.C., Rangwala, K.S., Rangwala, P.S. (1990). Water Supply and Sanitation Engineering (13 ${ }^{\text {th }}$ revised and enlarged edition), Court Road, Anand 388 001: Pradeep Publications.

The Rising Nepal (March 22, 2019). Safe water by 2030 a far cry, 97, p.1, Kathmandu, Nepal.

WHO (2017), Diarrhoeal disease, accessed on August, 2019, Retrieved from: https://www.who.int/newsroom/fact-sheets/detail/diarrhoeal-disease 